\title{
Effects of d-Amphetamine and Buprenorphine Combinations on Speedball (Cocaine + Heroin) Self-Administration by Rhesus Monkeys
}

\author{
Nancy K Mello*,' and S Stevens Negus' \\ 'Alcohol and Drug Abuse Research Center, Harvard Medical School-McLean Hospital, Belmont, MA, USA
}

\begin{abstract}
The simultaneous i.v. administration of heroin and cocaine, called a 'speedball,' is often reported clinically, and identification of effective pharmacotherapies is a continuing challenge. We hypothesized that treatment with combinations of a monoamine releaser $\mathrm{d}$-amphetamine, and a mu partial agonist, buprenorphine, might reduce speedball self-administration by rhesus monkeys. Speedballs $(0.01 \mathrm{mg} / \mathrm{kg} /$ inj cocaine $+0.0032 \mathrm{mg} / \mathrm{kg} / \mathrm{inj}$ heroin) and food ( $\mathrm{g}$ banana-flavored pellets) were available during four daily sessions on a second-order schedule of reinforcement (fixed ratio (FR)2 (variable ratio (VR) I6:S)). Monkeys were treated for 10 days with saline or ascending doses of $d$-amphetamine $(0.0032-0.032 \mathrm{mg} / \mathrm{kg} / \mathrm{h})+$ buprenorphine $(0.075$ or $0.237 \mathrm{mg} / \mathrm{kg} / \mathrm{day})$ in combination. $\mathrm{d}$-Amphetamine + both doses of buprenorphine produced an amphetamine dose-dependent decrease in speedball self-administration in comparison to the saline treatment baseline $(P<0.0 \mathrm{I}-0.00 \mathrm{I})$, but food-maintained responding did not change significantly. $\mathrm{d}$-Amphetamine alone $(0.032 \mathrm{mg} / \mathrm{kg} / \mathrm{h})$ significantly decreased both food $(P<0.0 \mathrm{l})$ and speedball-maintained responding $(P<0.05)$. During saline control treatment, speedball unit doses of $0.0032 \mathrm{mg} / \mathrm{kg} / \mathrm{inj}$ cocaine $+0.00 \mathrm{I} \mathrm{mg} / \mathrm{kg} / \mathrm{inj}$ heroin were at the peak of the speedball dose-effect curve. Daily treatment with $0.01 \mathrm{mg} / \mathrm{kg} / \mathrm{h}$ d-amphetamine $+0.237 \mathrm{mg} / \mathrm{kg} /$ day buprenorphine produced a significant downward and rightward shift in the speedball dose-effect curve $(P<0.0 \mathrm{I})$ and no significant effect on food-maintained responding. A significant decrease in speedball self-administration was sustained over 10 days of treatment. These findings are consistent with our previous reports and suggest that medication mixtures designed to target both the stimulant and the opioid component of the speedball may be an effective approach to polydrug abuse treatment.
\end{abstract}

Neuropsychopharmacology (2007) 32, 1985-1994; doi:I0.1038/sj.npp. I301319; published online 17 January 2007

Keywords: speedball; cocaine; heroin; $d$-amphetamine; buprenorphine; drug self-administration

\section{INTRODUCTION}

Cocaine use by methadone- and buprenorphine (suboxone)-maintained patients is reported by many treatment programs (Kosten et al, 1989; Condelli et al, 1991; Gastfriend et al, 1993; Schottenfeld et al, 1993; Bux et al, 1995; Downey et al, 2000; Beswick et al, 2001; Williamson et al, 2006). The concurrent abuse of cocaine and opioids has a number of adverse medical consequences including an enhanced risk for lethal drug overdose (NIDA, 2002). Emergency ward mentions and mortality data indicate that cocaine is the most common secondary illicit drug of abuse among primary heroin abusers (NIDA, 2002). The simultaneous intravenous administration of heroin and cocaine known as the 'speedball' is common among polydrug

*Correspondence: Dr NK Mello, Alcohol and Drug Abuse Research Center, Harvard Medical School-McLean Hospital, I I 5 Mill Street, Belmont, MA 02478, USA, Tel: + I 617855 2746, Fax: + 1617855 2519, E-mail: mello@mclean.harvard.edu

Received 29 June 2006; revised 21 November 2006; accepted 27 November 2006 abusers (Schütz et al, 1994) and concurrent cocaine and opioid abuse often continues during opioid agonist treatment (Beswick et al, 2001; Williamson et al, 2006). Speedball abuse may be associated with compromised immune function, and vulnerability to viral infections (AIDS, hepatitis) and bacterial infections (endocarditis, pulmonary infections, abscesses) (Schoenbaum et al, 1989; Kreek, 1991; Pillai et al, 1991; O'Brien, 1996). Treatment of dual dependence on cocaine and opioids presents a special challenge, because pharmacotherapies for opioid abuse usually are less effective in reducing cocaine abuse, and identification of a consistently effective pharmacotherapy for cocaine abuse remains elusive (Mendelson and Mello, 1996; Vocci et al, 2005).

The development of new pharmacological treatments can be facilitated by the availability of animal models of drug abuse for evaluating medication efficacy (Mello and Negus, 1996; Mello, 2005). We developed a model of speedball selfadministration in the rhesus monkey and studied the reinforcing effects of nine speedball combinations of cocaine $(0.001,0.01$, and $0.10 \mathrm{mg} / \mathrm{kg} / \mathrm{inj})$ and heroin 
(0.0001, 0.001, and $0.01 \mathrm{mg} / \mathrm{kg} / \mathrm{inj})$, and compared these with self-administration of cocaine alone and heroin alone (Mello et al, 1995). Intermediate doses of cocaine alone and heroin alone maintained equivalent high levels of drug selfadministration, and combinations of cocaine and heroin usually maintained levels of drug self-administration similar to those maintained by either cocaine or heroin alone (Mello et al, 1995). Dose-dependent decreases in foodmaintained responding occurred during cocaine, heroin, and speedball self-administration, but speedball self-administration was not associated with any other overt toxic effects over the period of observation (Mello et al, 1995).

We subsequently examined the effects of medication combinations designed to target the cocaine and the heroin component of speedball self-administration. We found that a combination of the dopamine antagonist flupenthixol and the opioid antagonist quadazocine was more effective in reducing both speedball self-administration and speedball discrimination than either antagonist alone (Negus et al, 1998; Mello and Negus, 1999). In addition, chronic treatment with a combination of the dopamine reuptake inhibitor indatraline and the partial mu opioid agonist buprenorphine significantly reduced speedball self-administration in comparison to saline treatment, whereas the same doses of each medication alone had no significant effect on speedball-maintained responding (Mello and Negus, 2001). These findings were consistent with our hypothesis that medication combinations designed to target both the stimulant and the opioid components of the speedball may be an effective approach to polydrug abuse treatment. This hypothesis has been supported by recent clinical reports that a combination of $d$-amphetamine and methadone reduced both cocaine and heroin use in heroin and cocaine abusers (Grabowski et al, 2004a).

We now report evaluation of the effects of another treatment medication combination, $d$-amphetamine + buprenorphine, on speedball self-administration by rhesus monkeys. We have previously reported that chronic administration of buprenorphine alone $(0.237 \mathrm{mg} / \mathrm{kg} /$ day $)$ selectively reduced speedball self-administration and shifted dose-effect curves for combinations of low doses of cocaine $(0.001 \mathrm{mg} / \mathrm{kg} / \mathrm{inj})$ and heroin $(0.0001-0.032 \mathrm{mg} / \mathrm{kg} / \mathrm{inj})$ downward and approximately one log unit to the right (Mello and Negus, 1998). However, when higher doses of cocaine $(0.01$ and $0.1 \mathrm{mg} / \mathrm{kg} / \mathrm{inj})$ were combined with heroin, this dose of buprenorphine was less effective in reducing speedball self-administration. Other doses of buprenorphine $(0.075$ or $0.75 \mathrm{mg} / \mathrm{kg} /$ day $)$ did not significantly decrease self-administration of a speedball combination of $0.01 \mathrm{mg} / \mathrm{kg} / \mathrm{inj}$ cocaine and $0.0032 \mathrm{mg} / \mathrm{kg} / \mathrm{inj}$ heroin (Mello and Negus, 1998). In contrast, buprenorphine (0.075 and $0.237 \mathrm{mg} / \mathrm{kg} /$ day) significantly reduced self-administration of heroin alone and shifted the heroin dose-effect curve (0.0001-0.10 mg/kg/inj) downwards and to the right (Mello and Negus, 1998).

The present study examined whether or not the addition of $d$-amphetamine to buprenorphine would decrease speedball-maintained responding more effectively than either $d$-amphetamine or buprenorphine alone. We choose $d$-amphetamine for study because it selectively decreased cocaine self-administration maintained on a second-order schedule and on a progressive ratio schedule (Negus and
Mello, 2003a, b) and in a cocaine $v s$ food choice procedure (Negus, 2003), but $d$-amphetamine's effects on speedballand food-maintained responding have not been examined previously. Buprenorphine reduced both opioid and cocaine self-administration in preclinical studies (for a review, see Mello and Mendelson, 1995; Mello, 2005). For example, buprenorphine decreased the self-administration of opioids (heroin and hydromorphone) (Mello et al, 1983; Mello and Negus, 1998); morphine (Harrigan and Downs, 1981); alfentanil (Winger et al, 1992), as well as cocaine in rhesus monkeys (Mello et al, 1989, 1990, 1992, 1993a, b; Winger et al, 1992; Lukas et al, 1995) and produced minimal and transient effects on food-maintained responding.

It is well established that buprenorphine reduces heroin self-administration in inpatient clinical studies (Mello and Mendelson, 1980; Mello et al, 1982) and opioid abuse in outpatient clinical trials (Johnson et al, 1992; Strain et al, 1994; for a review, see Bickel and Amass, 1995; Fudala and Johnson, 1995; Mello and Mendelson, 1995; Jones, 2004). Buprenorphine was approved by the FDA as a treatment for opioid abuse in 2002, and also reduced both opioid and cocaine use in outpatient studies of persons dependent on both cocaine and opioids (Kosten et al, 1989; Gastfriend et al, 1993; Schottenfeld et al, 1993; Mello and Mendelson, 1995; Montoya et al, 2004). In controlled clinical laboratory studies in polydrug abusers, buprenorphine (4 mg s.l.) decreased the number of choices of high doses of cocaine (16 and $32 \mathrm{mg} / 70 \mathrm{~kg}$ ) over tokens that could be exchanged for cigarettes, a variety of preferred foods and access to movies and music (Foltin and Fischman, 1994). It was concluded that buprenorphine may be more effective in reducing cocaine abuse in speedball users than in persons who use cocaine independently of opioids (Foltin and Fischman, 1995).

One goal of the present study was to evaluate the effects of chronic treatment with $d$-amphetamine + buprenorphine on the self-administration of a range of doses of cocaine + heroin speedball combinations by rhesus monkeys. A second goal was to examine the effects of $d$-amphetamine alone on speedball self-administration. Finally, this study also allowed us to compare preclinical and clinical findings because both $d$-amphetamine and buprenorphine have been studied in clinical trials (for a review, see Mello and Mendelson, 1995; Grabowski et al, 2004b). As we have discussed elsewhere, systematic comparison of clinical and preclinical medication evaluations is important for establishing the predictive validity of animal drug self-administration models (for a review, see Mello and Negus, 1996; Mello, 2005). This report is the first evaluation of the effects of a combination of the monoamine releaser, $d$-amphetamine and buprenorphine, an opioid mixed agonist-antagonist, on self-administration of cocaine and heroin (speedball) combinations in rhesus monkeys.

\section{METHODS}

\section{Subjects}

Four male rhesus monkeys (Macaca mulatta) that weighed between 6 and $12 \mathrm{~kg}$ were studied. All monkeys had selfadministered cocaine for at least 1 year before cocaine + 
heroin speedball combinations were made available for self-administration. Speedball-maintained responding was studied for at least 1 month before these studies began. Monkeys received multiple vitamins, fresh fruit and vegetables, and Lab Diet Jumbo Monkey Biscuits (PMI Feeds Inc., St Louis, MO) to supplement a banana-flavored pellet diet, fortified with vitamin C (P.J. Noyes Co., Lancaster, NH). Food supplements were given between 1700 and 1730 hours. Water was continuously available. A 12-h light-dark cycle was in effect (lights on 0700-1900 hours), and the experimental chamber was dark during food and drug self-administration sessions.

Animal maintenance and research were conducted in accordance with the guidelines provided by the Institute of Laboratory Animal Resources (ILAR-NRC, 1996). The facility is licensed by the US Department of Agriculture, and protocols were approved by the Institutional Animal Care and Use Committee. Monkeys were observed at least twice every day. Any changes in general activity were noted. The observer was not blind to the treatment condition. In addition, the health of the monkeys was periodically monitored by consultant veterinarians trained in primate medicine. Operant food and drug acquisition procedures provided an opportunity for enrichment and for monkeys to manipulate their environment (Line, 1987). Monkeys had visual, auditory, and olfactory contact with other monkeys throughout the study.

\section{Surgical Procedures}

Double lumen Silicone ${ }^{\circledR}$ rubber catheters (I.D. 0.028 in, O.D. 0.088 in) (Saint Gobain Performance Plastics, Beaverton, MI) were surgically implanted in the internal jugular, external jugular, or femoral vein to permit i.v. drug and treatment administration. All surgical procedures were performed under aseptic conditions. Monkeys were initially sedated with ketamine (5-10 mg/kg, i.m.), and anesthesia was induced with sodium thiopental $(10 \mathrm{mg} / \mathrm{kg}$, i.v.). Atropine $(0.05 \mathrm{mg} / \mathrm{kg})$ s.c. or i.m. was administered to reduce salivation. Following insertion of an endotracheal tube, anesthesia was maintained with isofluorane (1-2\% mixed with oxygen). After surgery, monkeys were given procaine penicillin $\mathrm{G}$ at $20000 \mathrm{U} / \mathrm{kg}$, i.m. twice daily for 5 days, or cephalexin $20 \mathrm{mg} / \mathrm{kg}$, p.o. twice daily for 5 days. An analgesic dose of buprenorphine $(0.032 \mathrm{mg} / \mathrm{kg}$, i.m.) was administered twice daily for 3 days.

The intravenous catheter exited in the mid-scapular region and was protected by a tether system consisting of a custom-fitted nylon vest connected to a flexible stainlesssteel cable and fluid swivel (Lomir Biomedical, Inc., Malone, NY). This flexible tether system permits monkeys to move freely. Catheter patency was evaluated periodically by administration of either a short-acting barbiturate, methohexital sodium $(3 \mathrm{mg} / \mathrm{kg})$, or ketamine $(5 \mathrm{mg} / \mathrm{kg})$ through the catheter lumen. If muscle tone decreased within $10 \mathrm{~s}$ after drug administration, the catheter was considered patent.

\section{Behavioral Procedures and Apparatus}

Monkeys were housed individually in stainless-steel chambers $(64 \times 64 \times 79 \mathrm{~cm})$ equipped with a custom-designed operant response panel $(28 \times 28 \mathrm{~cm})$, a pellet dispenser (Gerbrands Model G5210, Arlington, MA) and two syringe pumps (Model 981210, Harvard Apparatus, Inc., South Natick, MA), one for each lumen of the double-lumen catheter. During food self-administration sessions, the response key on the operant panel was illuminated with a red light, and responding under an FR2 (VR16:S) schedule resulted in presentation of a $1 \mathrm{~g}$ banana-flavored pellet (P.J. Noyes Co., Lancaster, NH). During drug self-administration sessions, the response key was illuminated with a green light, and responding under an FR2 (VR16:S) schedule resulted in delivery of $0.1 \mathrm{ml}$ of saline or a drug solution over $1 \mathrm{~s}$ through one lumen of the double-lumen catheter. A 10-s time-out followed delivery of each drug or saline injection or food pellet. Schedules of reinforcement were programmed with custom-designed software and IBMcompatible computers and interface systems (Med Associates, St Albans, VT). Additional details of this apparatus have been described previously (Mello et al, 1995).

Four food sessions and four drug sessions were conducted during each experimental day, and at all other times, responding had no scheduled consequences. Food sessions began at $0600,1100,1500$ and 1900 hours, and drug sessions began at 0700, 1200, 1600 and 2000 hours. Each food and drug session lasted for $1 \mathrm{~h}$ or until 25 food pellets or 20 injections had been delivered. Monkeys could earn a maximum of 100 food pellets per day and 80 injections per day. These behavioral procedures were identical to those used in our studies of the effects of $d$-amphetamine alone on cocaine self-administration (Negus and Mello, 2003a) and the effects of several drugs on speedball selfadministration (Mello and Negus, 1998, 1999, 2001).

\section{Drug Self-Administration Procedures}

All monkeys were trained to self-administer cocaine $(0.032 \mathrm{mg} / \mathrm{kg} / \mathrm{inj}$, i.v.) and subsequently given access to speedball combinations of cocaine and heroin. During speedball self-administration, cocaine and heroin were prepared in a single solution and delivered through one catheter lumen as in our previous studies (Mello et al, 1995; Mello and Negus, 1998, 1999). The simultaneous administration of cocaine and heroin combinations was designed to simulate one type of speedball self-administration reported clinically (Schütz et al, 1994).

Heroin and cocaine (speedball) dose combinations. The speedball combination studied was a 3 to 1 ratio of cocaine to heroin that consisted of $0.01 \mathrm{mg} / \mathrm{kg} / \mathrm{inj}$ cocaine in combination with $0.0032 \mathrm{mg} / \mathrm{kg} / \mathrm{inj}$ heroin. In our previous studies, these unit doses of cocaine alone and heroin alone each maintained high rates of drug self-administration at or near the peak of the cocaine and heroin dose-effect curves (Mello et al, 1995; Mello and Negus, 1998). Moreover, this cocaine +heroin combination maintained high rates of speedball self-administration in our previous studies (Mello et al, 1995; Mello and Negus, 1998, 1999, 2001).

\section{$d$-Amphetamine, Buprenorphine, and Saline Treatments}

$d$-Amphetamine treatment was implemented using a procedure identical to that used in our previous studies of 
the effects of $d$-amphetamine on cocaine self-administration (Negus and Mello, 2003a). Specifically, infusions of saline or $d$-amphetamine were administered through the intravenous catheter in volume of $0.1 \mathrm{ml}$ every $20 \mathrm{~min}$ from 1030 hours until 0930 hours the next morning, for a total of three injections per hour and 69 injections per day (total injection volume of $6.9 \mathrm{ml}$ ). Doses of $d$-amphetamine are described in $\mathrm{mg} / \mathrm{kg} / \mathrm{h}$. Buprenorphine was administered through the intravenous catheter in a volume of $0.1 \mathrm{ml}$ every minute from 0930 to 1020 hours for a total of 50 infusions in $50 \mathrm{~min}$ (total infusion volume of $5 \mathrm{ml}$ ). Doses of buprenorphine are described in $\mathrm{mg} / \mathrm{kg} /$ day. This procedure was identical to that used in our previous studies of the effects of buprenorphine on self-administration of cocaine alone, heroin alone, or speedball combinations of cocaine and heroin (Mello et al, 1989, 1990, 1992, 1993a, b; Mello and Negus, 1998).

\section{Sequence of $d$-Amphetamine + Buprenorphine Treatment Conditions}

The effects of daily treatment with saline, $d$-amphetamine alone, or $d$-amphetamine + buprenorphine in combination on speedball- and food-maintained responding were studied. Each treatment condition was in effect for 10 days to evaluate the time course of any effects observed (for a discussion, see Mello and Negus, 1996). At the end of each treatment condition, saline control treatment and the maintenance speedball dose $(0.01 \mathrm{mg} / \mathrm{kg} / \mathrm{inj}$ cocaine + $0.0032 \mathrm{mg} / \mathrm{kg} / \mathrm{inj}$ heroin) were in effect for at least 4 days, and until responding for cocaine and food returned to baseline levels. This interval of saline treatment was designed to prevent any effects of one treatment condition from influencing the effects of a subsequent treatment condition. The same procedures were used in our earlier reports of treatment medication effects on speedball selfadministration (Mello and Negus, 1998, 1999, 2001).

In Experiment 1, the effects of $d$-amphetamine alone $(0.032 \mathrm{mg} / \mathrm{kg} / \mathrm{h})$ and $d$-amphetamine + buprenorphine combinations on responding maintained by food and speedball doses of $0.01 \mathrm{mg} / \mathrm{kg} / \mathrm{inj}$ cocaine $+0.0032 \mathrm{mg} / \mathrm{kg} / \mathrm{inj}$ heroin were examined in four monkeys. Three doses of $d$ amphetamine $(0.0032,0.01$, and $0.032 \mathrm{mg} / \mathrm{kg} / \mathrm{h})$ were administered in combination with two doses of buprenorphine $(0.075$ or $0.237 \mathrm{mg} / \mathrm{kg} /$ day $)$. These relative and absolute doses of $d$-amphetamine + buprenorphine were based on our earlier studies that examined the potency of $d$-amphetamine in decreasing cocaine self-administration (Negus and Mello, 2003a) and the potency of buprenorphine in decreasing heroin self-administration in rhesus monkeys (Mello and Negus, 1998).

In Experiment 2, a speedball self-administration doseeffect curve was determined for six cocaine and heroin combinations: $0.00032 \mathrm{mg} / \mathrm{kg} / \mathrm{inj}$ cocaine $+0.0001 \mathrm{mg} / \mathrm{kg} / \mathrm{inj}$ heroin to $0.10 \mathrm{mg} / \mathrm{kg} / \mathrm{inj}$ cocaine $+0.032 \mathrm{mg} / \mathrm{kg} / \mathrm{inj}$ heroin. Each speedball dose combination was studied for 10 days during saline treatment. Then, the effects of treatment with a combination of $d$-amphetamine $(0.01 \mathrm{mg} / \mathrm{kg} /$ day $)+$ buprenorphine $(0.237 \mathrm{mg} / \mathrm{kg} /$ day $)$ on the speedball doseeffect curve were evaluated in three of the same monkeys. Each of the six speedball dose combinations was available for self-administration for 10 days during saline treatment and during $d$-amphetamine + buprenorphine treatment.

\section{Drugs}

Cocaine $\mathrm{HCl}$, heroin (3,6-diacetylmorphine $\mathrm{HCl}$ ), and buprenorphine $\mathrm{HCl}$ were obtained in crystalline form from the National Institute on Drug Abuse, NIH. The purity of cocaine and heroin was certified by Research Triangle Institute, Research Triangle Park, North Carolina, to be greater than $98 \%$. $d$-Amphetamine sulfate was purchased from Sigma Chemical Co. (St Louis, MO). All drugs were dissolved in sterile saline or sterile water, filter-sterilized using a $0.22 \mu \mathrm{m}$ Millipore filter, and stored in sterile, pyrogen-free vials. All doses were calculated using the salt forms of the drugs described above.

\section{Data Analysis}

The dependent variables were the number of saline or speedball injections per day and the number of food pellets per day. Statistical analyses were based on the mean $( \pm$ SEM $)$ number of injections and food pellets per day delivered during the last 3 days of a 10-day treatment condition. Changes in drug- and food-maintained responding during treatment with $d$-amphetamine and buprenorphine administered alone or in combination were statistically compared with the saline treatment baseline with an ANOVA for repeated measures and Contrast tests or Fishers post hoc tests. Huynh-Feldt Epsilon factors were used to adjust for degrees of freedom of within-group means (Super ANOVA Software Manual, Abacus Concepts, Inc., Berkeley, CA, 1989). In addition, the mean numbers of injections and food pellets delivered each day during a 10day availability of $0.0032 \mathrm{mg} / \mathrm{kg} / \mathrm{inj}$ cocaine $+0.001 \mathrm{mg} / \mathrm{kg} /$ inj heroin during treatment with saline or $0.01 \mathrm{mg} / \mathrm{kg} / \mathrm{h}$ amphetamine $+0.237 \mathrm{mg} / \mathrm{kg} / \mathrm{day}$ buprenorphine are shown graphically. Daily patterns of speedball- and food-maintained responding were compared with ANOVA for repeated measures on corresponding days during saline treatment and $d$-amphetamine + buprenorphine treatment.

\section{RESULTS}

\section{Experiment 1: Effects of Chronic $d$-Amphetamine + Buprenorphine Treatment on Speedball- and Food-Maintained Responding}

Figure 1 shows the effects of chronic treatment with saline, six combinations of $d$-amphetamine + buprenorphine, and one dose of $d$-amphetamine alone on responding maintained by speedball combinations and food pellets. During the saline baseline treatment, monkeys self-administered an average of $74 \pm 2.4$ (mean \pm SEM) speedball injections per day and $100( \pm 0)$ (mean \pm SEM) food pellets per day. $d$ Amphetamine and buprenorphine combinations produced an amphetamine dose-dependent decrease in speedballmaintained responding. Speedball self-administration decreased significantly during treatment with the highest dose of $d$-amphetamine $(0.032 \mathrm{mg} / \mathrm{kg} / \mathrm{h})$ in combination with each dose of buprenorphine $(0.075 \mathrm{mg} / \mathrm{kg} / \mathrm{day}$ and $0.237 \mathrm{mg} / \mathrm{kg} /$ day). When the same dose of $d$-amphetamine 


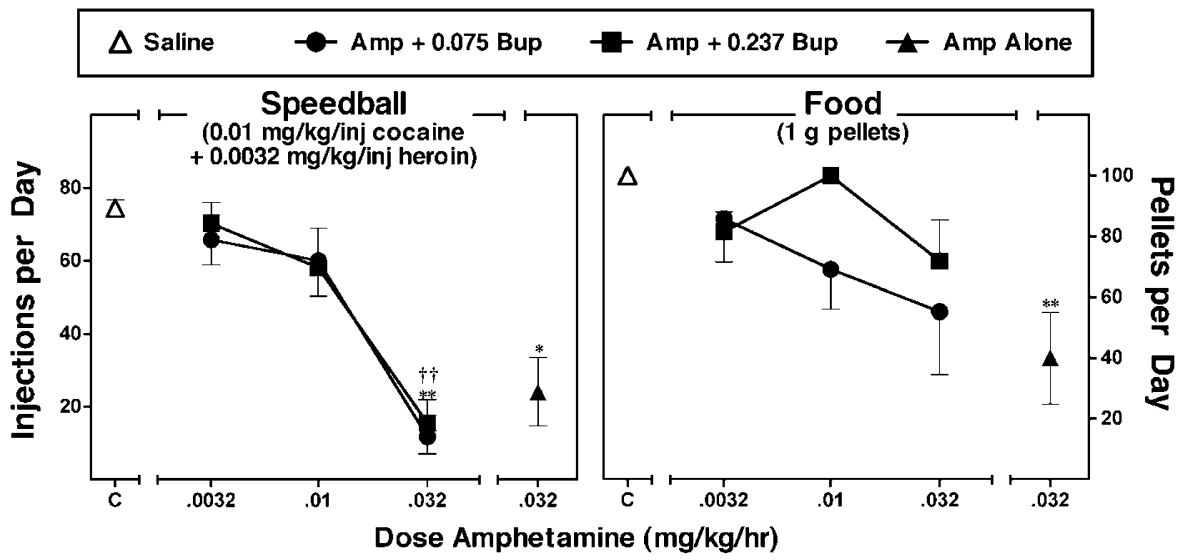

Figure I Effects of chronic treatment with saline, ascending doses of $d$-amphetamine + buprenorphine combinations, and $d$-amphetamine alone on speedball- and food-maintained responding: Speedball- and food-maintained responding are shown as open triangles during saline treatment, as closed

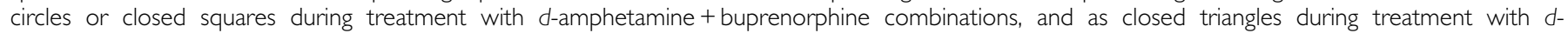

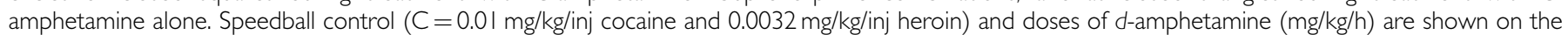

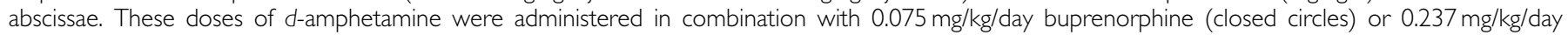

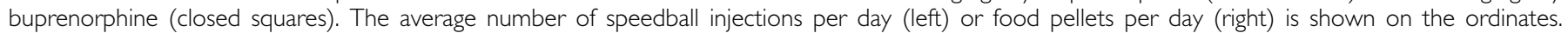

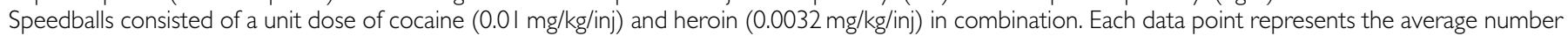

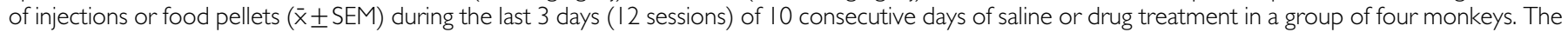

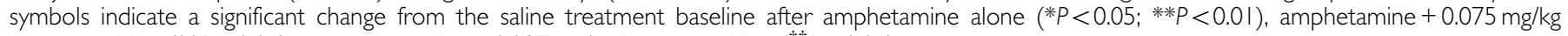
buprenorphine $(* * P<0.0 \mathrm{I})$, or amphetamine $+0.237 \mathrm{mg} / \mathrm{kg}$ buprenorphine $\left({ }^{\dagger \dagger} P<0.0 \mathrm{I}\right)$.

$(0.032 \mathrm{mg} / \mathrm{kg} / \mathrm{h})$ was administered alone, speedball selfadministration also decreased significantly below saline treatment baseline levels $(P<0.05)$. During treatment with $d$-amphetamine alone, speedball-maintained responding was slightly greater than when the same dose of $d$ amphetamine was combined with buprenorphine, but these differences were not statistically significant.

$d$-Amphetamine + buprenorphine did not significantly alter food-maintained responding, although food-maintained responding was decreased in some monkeys. There was a tendency for suppression of food-maintained responding to be amphetamine dose-dependent and greater during co-administration of the low dose of buprenorphine $(0.075 \mathrm{mg} / \mathrm{kg} /$ day $)$ than the high dose of buprenorphine $(0.237 \mathrm{mg} / \mathrm{kg} /$ day $)$. Food-maintained responding was significantly suppressed by $d$-amphetamine alone.

Experiment 2: Effects of Chronic Treatment with Saline or a $d$-Amphetamine + Buprenorphine Combination on the Speedball Dose-Effect Curve (Figure 2)

Saline treatment. Figure 2 shows the effects of the last 3 days of 10 days of treatment with saline or with a combination of $d$-amphetamine $(0.01 \mathrm{mg} / \mathrm{kg} / \mathrm{h})$ and buprenorphine $(0.237 \mathrm{mg} / \mathrm{kg} / \mathrm{day})$ on the speedball dose-effect curve and concurrent food-maintained responding. During saline treatment, when saline was available for selfadministration, monkeys took an average of $28.1 \pm 2.4$ (mean \pm SEM) injections per day and $94.9 \pm 5.1$ (mean \pm SEM) food pellets per day. When a 3:1 cocaine/heroin speedball combination was available during saline control treatment, the speedball dose-effect curve had an inverted$\mathrm{U}$ shape. The lowest speedball dose studied $(0.00032 \mathrm{mg} / \mathrm{kg} /$ inj cocaine $+0.0001 \mathrm{mg} / \mathrm{kg} /$ inj heroin) maintained responding similar to saline levels. Speedball doses over a range of $0.001 \mathrm{mg} / \mathrm{kg} / \mathrm{inj}$ cocaine $+0.00032 \mathrm{mg} / \mathrm{kg} /$ inj heroin to $0.01 \mathrm{mg} / \mathrm{kg} /$ inj cocaine $+0.0032 \mathrm{mg} / \mathrm{kg} /$ inj heroin each maintained significantly more responding than saline $(P<0.05-$ 0.01 ). A unit dose of $0.0032 \mathrm{mg} / \mathrm{kg} / \mathrm{inj}$ cocaine $+0.001 \mathrm{mg} /$ $\mathrm{kg} / \mathrm{inj}$ heroin was at the peak of the speedball dose-effect curve and maintained $79.6 \pm 0.4$ (mean \pm SEM) speedball injections per day. During saline treatment, food-maintained responding did not change significantly from baseline except at a speedball unit dose of $0.032 \mathrm{mg} / \mathrm{kg} / \mathrm{inj}$ cocaine $+0.01 \mathrm{mg} / \mathrm{kg} /$ inj heroin $(P<0.05)$.

d-amphetamine + buprenorphine treatment. Treatment with the $0.01 \mathrm{mg} / \mathrm{kg} / \mathrm{h} d$-amphetamine $+0.237 \mathrm{mg} / \mathrm{kg} /$ day buprenorphine combination produced a downward and rightward shift in the speedball self-administration doseeffect curve. Speedball unit doses on the ascending limb and the peak of the dose-effect curve, during saline treatment, maintained significantly lower levels of speedball selfadministration during $d$-amphetamine + buprenorphine treatment $(P<0.05-0.001)$. Moreover, in comparison to saline treatment, speedball doses of $0.001 \mathrm{mg} / \mathrm{kg} / \mathrm{inj}$ cocaine $+0.00032 \mathrm{mg} / \mathrm{kg}$ heroin and $0.0032 \mathrm{mg} / \mathrm{kg} / \mathrm{inj}$ cocaine + $0.001 \mathrm{mg} / \mathrm{kg} / \mathrm{inj}$ heroin maintained lower levels of responding during $d$-amphetamine + buprenorphine treatment $(P<0.05-0.01)$. Food-maintained responding during treatment with $d$-amphetamine + buprenorphine did not differ significantly from levels of food-maintained responding during saline treatment.

Figure 3 shows daily patterns of speedball- and foodmaintained responding during 10 days of treatment with saline or a combination of $0.01 \mathrm{mg} / \mathrm{kg} / \mathrm{h} d$-amphetamine + $0.237 \mathrm{mg} / \mathrm{kg} /$ day buprenorphine. This speedball dose $(0.0032 \mathrm{mg} / \mathrm{kg} / \mathrm{inj}$ cocaine $+0.001 \mathrm{mg} / \mathrm{kg} / \mathrm{inj}$ heroin $)$ is at the peak of the speedball dose-effect curve shown in 
Figure 2. During saline treatment, speedball self-administration did not change significantly across the 10-day period. During treatment with $d$-amphetamine + buprenorphine, speedball-maintained responding decreased from $63.3 \pm 10.5$ injections on day 1 to $23.0 \pm 13.1$ injections on day 10 (left panel). Speedball injections were significantly lower than during saline treatment on days 7 through 10 $(P<0.05)$. Speedball self-administration decreased to
$36.3 \pm 11.8$ injections per day by the seventh day of treatment and remained significantly below baseline throughout the remainder of the treatment period. During saline treatment, food-maintained responding averaged between 94.3 and 100 pellets per day (right panel). Foodmaintained responding did not change significantly from saline treatment levels throughout the 10 days of $d$-amphetamine + buprenorphine treatment.

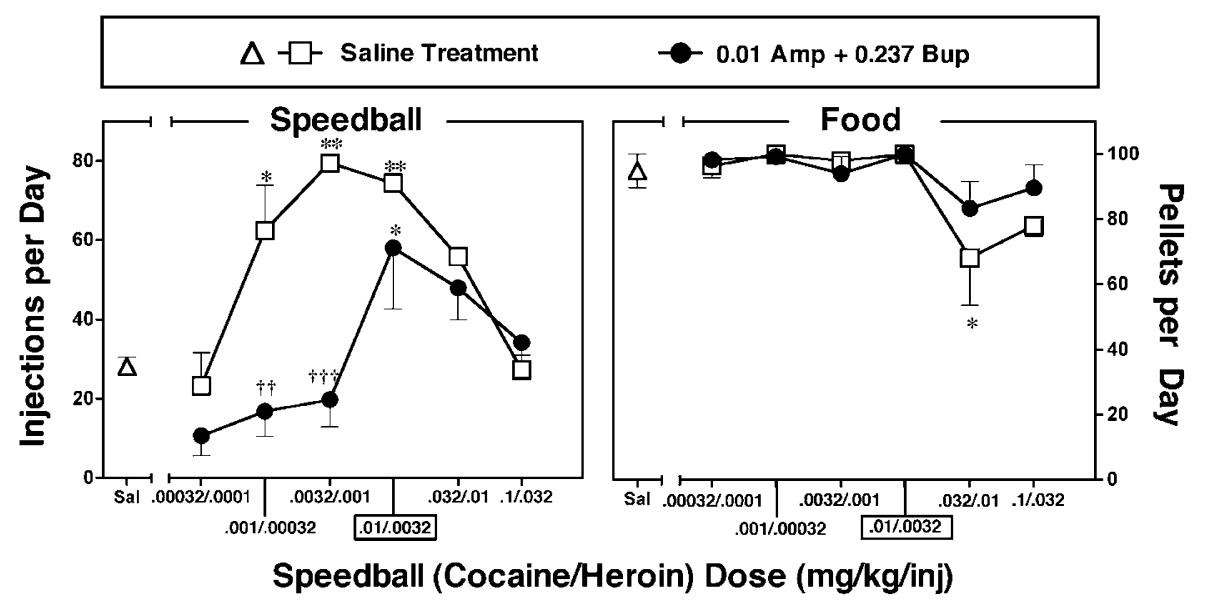

Figure 2 Effects of chronic treatment with saline or a d-amphetamine + buprenorphine combination on speedball dose-effect curves: Dose-effect curves for speedball combinations of cocaine $(0.00032-0.10 \mathrm{mg} / \mathrm{kg} / \mathrm{inj})$ and heroin $(0.000 \mathrm{I}-0.032 \mathrm{mg} / \mathrm{kg} / \mathrm{inj})$ are shown for a group of three monkeys (left panel). The unit doses of each cocaine and heroin combination are shown on the abscissae. The training dose is indicated by a box around one speedball dose combination ( $0.01 \mathrm{mg} / \mathrm{kg} / \mathrm{inj}$ cocaine $+0.0032 \mathrm{mg} / \mathrm{kg} / \mathrm{inj}$ heroin). Injections per day are shown on the left ordinate. Points above 'Sal' show data when saline was the solution available for self-administration. Self-administration of each cocaine-heroin combination during saline treatment is shown as open squares. Speedball self-administration during treatment with the $\mathrm{d}$-amphetamine $(0.01 \mathrm{mg} / \mathrm{kg} / \mathrm{h})+$ buprenorphine $(0.237 \mathrm{mg} / \mathrm{kg} / \mathrm{day})$ combination is shown as closed circles. Food-maintained responding during saline self-administration and self-administration of speedball cocaine and heroin combinations during saline treatment (open squares) is shown in the right panel. The number of food pellets self-administered per day is shown on the right ordinate. Food-maintained responding during treatment with $d$-amphetamine $(0.01 \mathrm{mg} / \mathrm{kg} / \mathrm{h})+$ buprenorphine $(0.237 \mathrm{mg} / \mathrm{kg} / \mathrm{day})$ is shown as closed circles. Each data point is the average of the last 3 days ( 12 sessions) of 10 consecutive days of speedball or food self-administration in a group of three monkeys ( $\bar{x} \pm$ SEM). The asterisks indicate a significant difference from saline self-administration during saline treatment $(* P<0.05 ; * * P<0.01)$. The daggers indicate that the number of speedball injections self-administered at the same speedball dose combinations were significantly different during saline treatment and during $d$-amphetamine + buprenorphine treatment $\left({ }^{\dagger \dagger} P<0.01\right.$; $\left.{ }^{\dagger \dagger} P<0.001\right)$.

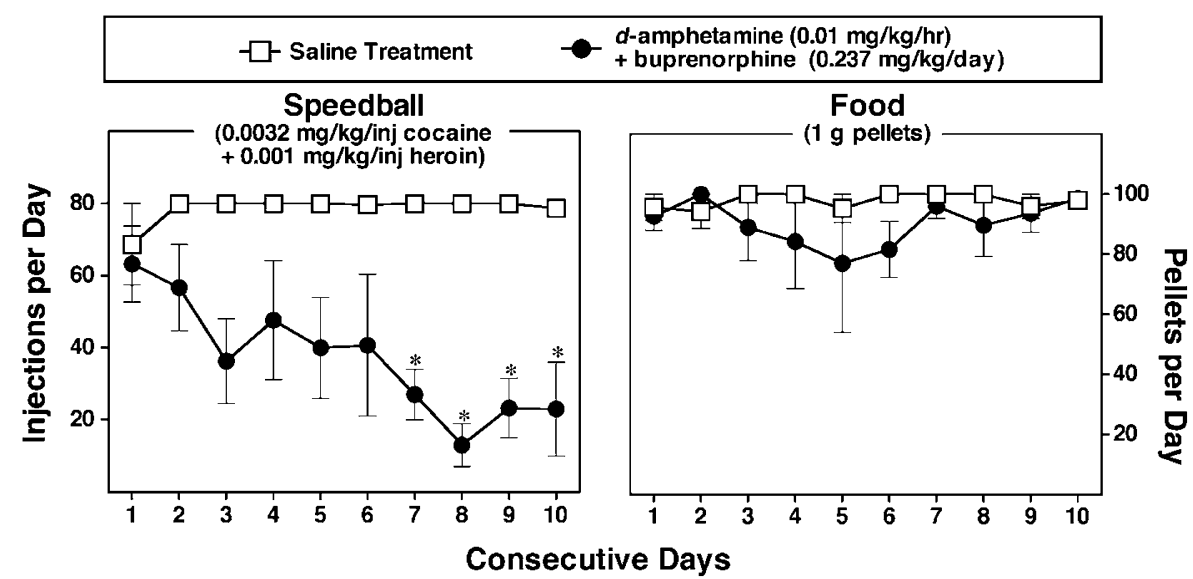

Figure 3 Effects of chronic treatment with saline or a d-amphetamine + buprenorphine combination on daily speedball-and food-maintained responding: Consecutive days of treatment are shown on the abscissae. Speedball injections per day are shown on the left ordinate and food pellets per day are shown on the right ordinate. Speedballs consisted of a unit dose of cocaine $(0.0032 \mathrm{mg} / \mathrm{kg} / \mathrm{inj})+$ heroin $(0.00 \mathrm{I} \mathrm{mg} / \mathrm{kg} / \mathrm{inj})$. Average speedball and food selfadministration per day $(\bar{x} \pm$ SEM) during 10 days of saline treatment are shown as open squares and during combined $d$-amphetamine + buprenorphine treatment are shown as closed circles. Each data point is based on three monkeys. The asterisks indicate those days on which speedball self-administration was significantly different during the $d$-amphetamine + buprenorphine treatment than during the saline treatment $(* P<0.05)$. 


\section{DISCUSSION}

\section{Effects of $d$-Amphetamine + Buprenorphine} Combinations on Speedball Self-Administration

This is the first report that a combination of $d$-amphetamine + buprenorphine selectively reduced cocaine + heroin (speedball) self-administration in rhesus monkeys, and this effect persisted during 10 days of treatment. This medication combination was chosen because $d$-amphetamine alone selectively reduced cocaine self-administration by nonhuman primates in three behavioral procedures (Negus, 2003; Negus and Mello, 2003a,b), and buprenorphine alone selectively reduced both cocaine and opioid self-administration in both clinical and preclinical studies (Mello et al, 1989; Mello and Negus, 1998; Montoya et al, 2004; for a review, see Bickel and Amass, 1995; Jones, 2004; Mello and Mendelson, 1995; Mello, 2005). Food-maintained responding during $d$-amphetamine + high-dose buprenorphine treatment was not significantly different from food-maintained responding during saline control treatment. $d$-Amphetamine alone also reduced speedball self-administration significantly, but in contrast to our previous studies of $d$-amphetamine's effects on cocaine alone, this effect was not selective (Negus, 2003; Negus and Mello, 2003a, b).

Results of the present study support the hypothesis that a combination of medications that target both the cocaine and the heroin component of the speedball might reduce self-administration more effectively than only one of the same medications alone (Hemby et al, 1996; Mello and Negus, 1999). These findings are also consistent with our previous reports that combinations of the dopamine antagonist flupenthixol and the opioid antagonist quadazocine, as well as combinations of the dopamine reuptake inhibitor indatraline and the partial mu opioid agonist buprenorphine, significantly reduced speedball self-administration by rhesus monkeys, whereas the same doses of each medication alone had no significant effect (Mello and Negus, 1999, 2001). In the present study, the combination of $d$-amphetamine + buprenorphine was also more effective than buprenorphine alone in reducing self-administration of speedballs consisting of high doses of cocaine + heroin (Mello and Negus, 1998). In rodents, microinjection of a combination of a dopamine D1 receptor antagonist and a $\mathrm{mu}$ receptor antagonist into the nucleus accumbens dosedependently decreased i.v. speedball self-administration maintained on a progressive ratio schedule, and this combination reduced motor activity less than either antagonist alone (Cornish et al, 2005). A dual medication approach to the treatment of speedball abuse assumes that the interactions between cocaine and heroin are critical determinants of the abuse-related effects of speedballs. Yet there remains considerable disagreement about the nature of that interaction.

Most preclinical studies of speedball effects are consistent with anecdotal clinical reports (Brecher, 1972; Schütz et al, 1994) and with findings from controlled clinical laboratory studies that mu opioid agonists usually enhance the abuserelated effects of cocaine (Foltin and Fischman, 1992, 1995; Preston et al, 1996; Walsh et al, 1996). In rhesus monkeys and in rodents, combinations of cocaine and mu opioids appear to be more reinforcing than either component drug alone under most (Mattox et al, 1997; Rowlett and
Woolverton, 1997; Duvauchelle et al, 1998; Ranaldi and Munn, 1998; David et al, 2001; Wang et al, 2001; Rowlett et al, 2005; Smith et al, 2006; Winger et al, 2006) but not all conditions (Mello et al, 1995; Hemby et al, 1996; Ward et al, 2005). For example, cocaine and heroin at unit doses that did not maintain self-administration alone were significantly more reinforcing than saline when combined in a speedball in rhesus monkeys (Rowlett and Woolverton, 1997; Rowlett et al, 2005). The relative efficacy of opioids at $\mathrm{mu}$ receptors did not appear to influence the enhanced reinforcing effects of speedballs when the opioid component consisted of the high-efficacy agonist alfentanil and the low efficacy agonist nalbuphine (Rowlett et al, 2005). Cocaine self-administration was enhanced at relatively low doses of heroin, alfentanil, and nalbuphine, even though nalbuphine alone did not maintain self-administration (Rowlett et al, 2002). In addition, microdialysis studies in rats indicate that cocaine + heroin mixtures increase levels of extracellular dopamine significantly above levels measured after cocaine or heroin alone (Hemby et al, 1999). Another microdialysis study found that a cocaine + heroin combination produced supra-additive effects on extracellular dopamine from the nucleus accumbens in comparison to heroin alone (Smith et al, 2006).

Several investigators have attempted to clarify the nature of the interactions between cocaine and opioid combinations using mathematical approaches. Isobolographic analyses of choice between food pellets and heroin or cocaine alone or cocaine + heroin mixtures by rhesus monkeys were interpreted to indicate that the effects of these drug combinations were additive or sub-additive, not superadditive (Negus, 2005). In rats, isobolographic analysis of the ascending limb of the i.v. cocaine, heroin, and cocaine + heroin self-administration dose-effect curve also indicated that the combination of cocaine + heroin produced an additive effect relative to cocaine or heroin alone (Smith et al, 2006). In contrast, behavioral economic analyses of demand curves for combined opioid and cocaine selfadministration by rhesus monkeys have yielded inconsistent findings (Mattox et al, 1997; Rowlett et al, 2005; Winger et al, 2006).

\section{Effects of $d$-Amphetamine + Buprenorphine Combinations on Food-Maintained Responding}

During saline treatment, food-maintained responding remained relatively stable across the range of speedball doses studied except at the highest doses $(0.032 \mathrm{mg} / \mathrm{kg} / \mathrm{inj}$ cocaine $+0.01 \mathrm{mg} / \mathrm{kg} / \mathrm{inj}$ heroin). This speedball dose decreased food-maintained responding significantly during saline treatment, but not during $d$-amphetamine + buprenorphine treatment. These findings suggest that buprenorphine antagonized the rate-decreasing effects of the highest speedball dose on food-maintained responding. Consistent with this interpretation, speedball self-administration during treatment with $d$-amphetamine + a low dose of buprenorphine $(0.075 \mathrm{mg} / \mathrm{kg})$ produced a greater reduction in food-maintained responding than during treatment with $d$-amphetamine + a higher dose of buprenorphine $(0.237 \mathrm{mg} / \mathrm{kg})$.

The relative stability of food-maintained responding during treatment with $d$-amphetamine and buprenorphine 
combinations is consistent with our previous findings with each drug alone. $d$-Amphetamine over a dose range of $0.01-$ $0.10 \mathrm{mg} / \mathrm{kg} / \mathrm{h}$ had less effect on food-maintained responding than on cocaine self-administration maintained on a second-order schedule or a progressive ratio schedule (Negus and Mello, 2003a,b), or a food vs cocaine choice procedure (Negus, 2003). During 28 days of chronic treatment with $d$-amphetamine $(0.10 \mathrm{mg} / \mathrm{kg} / \mathrm{h})$, food-maintained responding remained at baseline levels after an initial suppression for seven days (Negus and Mello, 2003b). Similarly, in the present study during speedball selfadministration and 10 days of treatment with amphetamine alone $(0.032 \mathrm{mg} / \mathrm{kg} / \mathrm{h})$, food-maintained responding was significantly lower than during the saline treatment baseline.

Buprenorphine usually produced an initial transient decrease in food-maintained responding during cocaine, heroin, or speedball self-administration on a second-order schedule (Mello et al, 1989, 1992; Mello and Negus, 1998; for a review, see Mello and Mendelson, 1995). However, foodmaintained responding returned to saline treatment baseline levels within 2 or 3 days, and did not decrease significantly even during 4 months of chronic buprenorphine treatment (Mello et al, 1992). The transient and minimal effects of buprenorphine on food-maintained responding during drug self-administration appear to be a consistent pattern. The extent to which this reflects the development of tolerance to buprenorphine's effects or buprenorphine's antagonism of the rate-decreasing effects of cocaine, heroin, and speedballs cannot be determined with certainty from these data. Importantly, in the present study, the decreases in speedball self-administration during $d$-amphetamine + buprenorphine treatment were selective and could not be explained by a general suppression of operant behavior.

\section{Implications for Preclinical Evaluation of Medications for Drug Abuse Treatment}

The major finding of the present study is that a combination of $d$-amphetamine + buprenorphine significantly reduced speedball self-administration and shifted the speedball dose-effect curve downwards and to the right in rhesus monkeys. Assessing the clinical relevance of animal models of drug self-administration is challenging, because many of the potential treatment medications that are effective in preclinical studies have not been approved by the FDA for evaluation in man. Consequently, there are relatively few opportunities for cross validation of medication effectiveness between preclinical studies and clinical trials (Mello and Negus, 1996; Mello, 2005). Fortunately, both $d$-amphetamine and buprenorphine have been used clinically, so it is possible to compare the degree of concordance between preclinical and clinical studies. Data in the present study are concordant with reports that the combination of $d$-amphetamine and methadone effectively reduced both cocaine and heroin use in polydrug abusers (Grabowski et al, 2004a, b). The effectiveness of $d$-amphetamine for the treatment of cocaine abuse in stimulant abusers has been demonstrated in a series of clinical studies (for a review, see Grabowski et al, 2004a). d-Amphetamine also selectively reduces cocaine self-administration by rhesus monkeys with minimal effects on food-maintained responding (Negus, 2003; Negus and Mello, 2003a, b). Buprenorphine consistently reduces cocaine self-administration in both clinical and preclinical studies (Mello and Mendelson, 1995). Buprenorphine also reduces heroin and speedball self-administration in both clinical and preclinical studies (Mello and Mendelson, 1995; Mello and Negus, 1998; Montoya et al, 2004; Negus, 2006). Taken together, these clinical and preclinical data suggest that this speedball selfadministration model in non-human primates is useful for evaluation of new pharmacotherapies for drug abuse treatment (Mello, 2005).

\section{ACKNOWLEDGEMENTS}

We thank Peter A Fivel, Melissa Timm, and Cara Sylvester for excellent technical assistance. We are grateful to Prabhat Seghal, DVM, for veterinary assistance and to Inge Knudson for her contributions to the data analysis. Preliminary data were reported at the 2004 annual meeting of the American College of Neuropsychopharmacology. This research was supported in part by KO5-DA00101 and P01-DA14528 from the National Institute on Drug Abuse, NIH.

\section{REFERENCES}

Beswick T, Best D, Rees S, Coomber R, Gossup M, Strang J (2001). Multiple drug use: patterns and practices of heroin and crack use in a population of opiate addicts in treatment. Drug Alcohol Rev 20: 201-204.

Bickel WK, Amass L (1995). Buprenorphine treatment of opioid dependence: a review. Exp Clin Psychopharmacol 3: 477-489.

Brecher EM (1972). Licit and Illicit Drugs - The Consumers Union Report. Little Brown and Company: Boston.

Bux DA, Lamb RJ, Iguchi MY (1995). Cocaine use and HIV risk behavior in methadone maintenance patients. Drug Alcohol Depend 37: 29-35.

Condelli WS, Fairbank JA, Dennis ML, Rachal JV (1991). Cocaine use by clients in methadone programs: significance, scope, and behavioral interventions. J Subst Abuse Treat 8: 203-212.

Cornish JL, Lontos JM, Clemens KJ, McGregor IS (2005). Cocaine and heroin ('speedball') self-administration: the involvement of nucleus accumbens dopamine and m-opiate, but not d-opiate receptors. Psychopharmacology 180: 21-32.

David V, Polis I, McDonald J, Gold LH (2001). Intravenous selfadministration of heroin/cocaine combinations (speedball) using nose-poke or lever-press operant responding in mice. Behav Pharmcol 12: 25-34.

Downey KK, Helmus TC, Schuster CR (2000). Treatment of heroindependent poly-drug abusers with contingency management and buprenorphine maintenance. Exp Clin Psychopharmacol 8: 176-184.

Duvauchelle CL, Sapoznik T, Kornetsky C (1998). The synergistic effects of combining cocaine and heroin ('speedball') using a progressive-ratio schedule of drug reinforcement. Pharm Biochem Behav 67: 297-302.

Foltin RW, Fischman MW (1992). The cardiovascular and subjective effects of intravenous cocaine and morphine combinations in humans. J Pharmacol Exp Ther 261: 623-632.

Foltin RW, Fischman MW (1994). Effects of buprenorphine on the self-administration of cocaine by humans. Behav Pharmacol 5 : 79-89.

Foltin RW, Fischman MW (1995). The interaction of buprenorphine with cocaine-morphine combinations. Exp Clin Psychopharmacol 3: 261-269. 
Fudala PJ, Johnson RE (1995). Clinical efficacy studies of buprenorphine for the treatment of opiate dependence. In: Cowan A, Lewis JW (eds). Buprenorphine: Combatting Drug Abuse With a Unique Opioid. Wiley-Liss, Inc.: New York. pp 213-239.

Gastfriend DR, Mendelson JH, Mello NK, Teoh SK, Reif S (1993). Buprenorphine pharmacotherapy for concurrent heroin and cocaine dependence. Am J Addict 2: 269-278.

Grabowski J, Rhoades H, Stotts A, Cowan K, Kopecky C, Dougherty A et al (2004a). Agonist-like or antagonist-like treatment for cocaine dependence with methadone for heroin dependence: two double-blind randomized clinical trials. Neuropsychopharmacology 29: 969-981.

Grabowski J, Shearer J, Merrill J, Negus SS (2004b). Agonist-like, replacement pharmotherapy for stimulant abuse and dependence. Addictive Behaviors (Special Issue: Crossing boundaries: implications of advances in basic sciences for the management of addition). Addict Behav 29: 1439-1464.

Harrigan SE, Downs DA (1981). Pharmacological evaluation of narcotic antagonist delivery systems in rhesus monkeys. In: Willette RE, Barnett G (eds). Narcotic Antagonists: Naltrexone Pharmacochemistry and Sustained-Release Preparations. US Government Printing Office: Washington, DC. pp 77-92.

Hemby SE, Co C, Dworkin SI, Smith JE (1999). Synergistic elevations in nucleus accumbens extracellular dopamine concentrations during self-administration of cocaine/heroin combinations (speedball) in rats. J Pharmacol Exp Ther 288: 274-280.

Hemby SE, Smith JE, Dworkin SI (1996). The effects of eticlopride and naltrexone on responding maintained by food, cocaine, heroin and cocaine/heroin combinations in rats. J Pharmacol Exp Ther 277: 1247-1258.

ILAR-NRC (1996). Guide for the Care and Use of Laboratory Animals. National Academy Press: Washington, DC.

Johnson RE, Jaffe JH, Fudala PJ (1992). A controlled trial of buprenorphine treatment for opioid dependence. J Am Med Assoc 267: 2750-2755.

Jones HE (2004). Practical considerations for the clinical use of buprenorphine. Sci Practice Perspect 2: 4-19.

Kosten TR, Kleber HD, Morgan C (1989). Treatment of cocaine abuse with buprenorphine. Biol Psychiatry 26: 170-172.

Kreek MJ (1991). Multiple drug abuse patterns: recent trends and associated medical consequences. In: Mello NK (ed). Advances in Substance Abuse, Behavioral and Biological Research. Jessica Kingsley Publishers: London. pp 91-112.

Line SW (1987). Environmental enrichment for laboratory primates. JAVMA 90: 854-859.

Lukas SE, Mello NK, Drieze JM, Mendelson JH (1995). Buprenorphine-induced alterations of cocaine's reinforcing properties in rhesus monkey: a dose-response analysis. Drug Alcohol Depend 40: 87-98.

Mattox AJ, Thompson SS, Carroll ME (1997). Smoked heroin and cocaine base (speedball) combinations in rhesus monkeys. Exp Clin Psychopharmacol 5: 113-118.

Mello NK (2005). Evaluation of drug abuse treatment medications: concordance between clinical and preclinical studies. In: Dewey WL (ed). NIDA Research Monograph No. 185. US Department of Health and Human Services, National Institutes of Health: Washington, DC. pp 82-104.

Mello NK, Bree MP, Mendelson JH (1983). Comparison of buprenorphine and methadone effects on opiate self-administration in primates. J Pharmacol Exp Ther 225: 378-386.

Mello NK, Kamien JB, Lukas SE, Mendelson JH, Drieze JM, Sholar JW (1993a). Effects of intermittent buprenorphine administration on cocaine self-administration by rhesus monkeys. J Pharmacol Exp Ther 264: 530-541.

Mello NK, Lukas SE, Kamien JB, Mendelson JH, Drieze J, Cone EJ (1992). The effects of chronic buprenorphine treatment on cocaine and food self-administration by rhesus monkeys. J Pharmacol Exp Ther 260: 1185-1193.

Mello NK, Lukas SE, Mendelson JH, Drieze J (1993b). Naltrexonebuprenorphine interactions: effects on cocaine self-administration. Neuropsychopharmacology 9: 211-224.

Mello NK, Mendelson JH (1980). Buprenorphine suppresses heroin use by heroin addicts. Science 27: 657-659.

Mello NK, Mendelson JH (1995). Buprenorphine treatment of cocaine and heroin abuse. In: Cowan A, Lewis JW (eds). Buprenorphine: Combatting Drug Abuse With a Unique Opioid. John Wiley \& Sons, Inc.: New York. pp 243-287.

Mello NK, Mendelson JH, Bree MP, Lukas SE (1989). Buprenorphine suppresses cocaine self-administration by rhesus monkey. Science 245: 859-862.

Mello NK, Mendelson JH, Bree MP, Lukas SE (1990). Buprenorphine and naltrexone effects on cocaine self-administration by rhesus monkeys. J Pharmacol Exp Ther 254: 926-939.

Mello NK, Mendelson JH, Kuehnle JC (1982). Buprenorphine effects on human heroin self-administration: an operant analysis. J Pharmacol Exp Ther 223: 30-39.

Mello NK, Negus SS (1996). Preclinical evaluation of pharmacotherapies for treatment of cocaine and opiate abuse using drug self-administration procedures. Neuropsychopharmacology 14: $375-424$.

Mello NK, Negus SS (1998). The effects of buprenorphine on selfadministration of cocaine and heroin 'speedball' combinations and heroin alone by rhesus monkeys. J Pharmacol Exp Ther 285: 444-456.

Mello NK, Negus SS (1999). Effects of flupenthixol and quadazocine on self-administration of speedball combinations of cocaine and heroin by rhesus monkeys. Neuropsychopharmacology 21: 575-588.

Mello NK, Negus SS (2001). Effects of indatraline and buprenorphine on self-administration of speedball combinations of cocaine and heroin by rhesus monkeys. Neuropsychopharmacology 25: 104-117.

Mello NK, Negus SS, Lukas SE, Mendelson JH, Sholar JW, Drieze J (1995). A primate model of polydrug abuse: cocaine and heroin combinations. J Pharmacol Exp Ther 274: 1325-1337.

Mendelson JH, Mello NK (1996). Management of cocaine abuse and dependence. $N$ Engl J Med 334: 965-972.

Montoya ID, Gorelick DA, Preston KL, Schroeder JR, Umbricht A, Cheskin LJ et al (2004). Randomized trial of buprenorphine for treatment of concurrent opiate and cocaine dependence. Clin Pharmacol Ther 75: 34-48.

Negus SS (2003). Rapid assessment of choice between cocaine and food in rhesus monkeys: effects of environmental manipulations and treatment with $d$-amphetamine and flupenthixol. Neuropsychopharmacology 28: 919-931.

Negus SS (2005). Interactions between the reinforcing effects of cocaine and heroin in a drug $v s$ food choice procedure in rhesus monkeys: a dose-addition analysis. Psychopharmacology 180: $115-124$

Negus SS (2006). Choice between heroin and food in nondependent and heroin-dependent rhesus monkeys: effects of naloxone, buprenorphine and methadone. J Pharmacol Exp Ther 317: 711-723.

Negus SS, Gatch MB, Mello NK (1998). Discriminative stimulus effects of a cocaine/heroin 'speedball' combination in rhesus monkeys. J Pharmacol Exp Ther 285: 1123-1136.

Negus SS, Mello NK (2003a). Effects of chronic $d$-amphetamine treatment on cocaine- and food-maintained responding under a second-order schedule in rhesus monkeys. Drug Alcohol Depend 70: $39-52$.

Negus SS, Mello NK (2003b). Effects of chronic $d$-amphetamine treatment on cocaine- and food-maintained responding under a progressive-ratio schedule in rhesus monkeys. Psychopharmacology 167: 324-332. 
NIDA (2002). Epidemiologic trends in drug abuse. NIH Publ No 3-5109A 1: 71 .

O’Brien CP (1996). Drug addiction and drug abuse. In: Goodman LS, Gilman A (eds). The Pharmacological Basis of Therapeutics. McGraw Hill Co.: New York. pp 557-577.

Pillai R, Nair BS, Watson RR (1991). AIDS, drugs of abuse and the immune system: a complex immunotoxicological network. Arch Toxicol 65: 609-617.

Preston KL, Sullivan JT, Strain EC, Bigelow GE (1996). Enhancement of cocaine's abuse liability in methadone maintenance patients. Psychopharmacology 123: 15-25.

Ranaldi R, Munn E (1998). Polydrug self-administration in rats: cocaine-heroin is more rewarding than cocaine-alone. Neuro Report 9: 2463-2466.

Rowlett JK, Rodefer JS, Spealman RD (2002). Self-administration of cocaine, alfentanil, and nalbuphine under progressive-ratio schedules: consumer demand and labor supply analyses of relative reinforcing effectiveness. Exp Clin Psychopharmacol 10: 367-375.

Rowlett JK, Rodefer JS, Spealman RD (2005). Self-Administration of cocaine-opioid combinations by rhesus monkeys: evaluation of the role of mu receptor efficacy using labor supply analysis. J Pharmacol Exp Ther 312: 1289-1297.

Rowlett JK, Woolverton WL (1997). Self-administration of cocaine and heroin combinations by rhesus monkeys responding under a progressive-ratio schedule. Psychopharmacology (Berl) 133: 363-371.

Schoenbaum EE, Hartel D, Selwyn PA, Klein RS, Davenny K, Rogers $M$ et al (1989). Risk factors for human immunodeficiency virus infection in intravenous drug users. $N$ Eng J Med 321: 874-879.

Schottenfeld RS, Pakes J, Ziedonis D, Kosten TR (1993). Buprenorphine: dose-related effects on cocaine and opioid use in cocaineabusing opioid-dependent humans. Biol Psychiatry 3: 66-74.

Schütz CG, Vlahov D, Anthony JC, Graham NMH (1994). Comparison of self-reported injection frequencies for past 30 days and 6 months among intravenous drug users. J Clin Epidemiol 47: 191-195.

Smith JE, Co C, Coller MD, Hemby SE, Martin TJ (2006). Selfadministered heroin and cocaine combinations in the rat: additive reinforcing effects-supra-additive effects on nucleus accumbens extracellular dopamine. Neuropsychopharmacology 31: $139-150$.

Strain EC, Stitzer ML, Liebson IA, Bigelow GE (1994). Comparison of buprenorphine and methadone in the treatment of opioid dependence. Am J Psychiatry 151: 1025-1030.

Vocci FJ, Acri J, Elkashef A (2005). Medication development for addictive disorders: the state of the science. Am J Psychiatry 162: $1432-1440$

Walsh SL, Sullivan JT, Preston KL, Garner J (1996). The effects of naltrexone on response to i.v. cocaine, hydromorphone and their combination in humans. J Pharmacol Exp Ther 279: 524-538.

Wang NS, Brown VL, Grabowski J, Meisch RA (2001). Reinforcement by orally delivered methadone, cocaine, and methadonecocaine combinations in rhesus monkeys: are the combinations better reinforcers? Psychopharmacology (Berl) 156: 63-72.

Ward SJ, Morgan D, Roberts DCS (2005). Comparison of the reinforcing effects of cocaine and cocaine/heroin combinations under progressive ratio and choice schedules in rats. Neuropsychopharmacology 30: 286-295.

Williamson A, Darke S, Ross J, Teesson M (2006). The effect of persistence of cocaine use on 12-month outcomes for the treatment of heroin dependence. Drug Alc Depend 81: 293-300.

Winger G, Galuska CM, Hursh SR, Woods JH (2006). Relative reinforcing effects of cocaine, remifentanil, and their combination in rhesus monkeys. J Pharmacol Exp Ther 318: 223-229.

Winger G, Skjoldager P, Woods JH (1992). Effects of buprenorphine and other opioid agonists and antagonists on alfentaniland cocaine-reinforced responding in rhesus monkeys. J Pharmacol Exp Ther 261: 311-317. 